\title{
THE HISTORICAL ROOTS OF AMAZIGH AND ITS ARABIZATION FACTORS IN ALGERIA
}

\author{
Ahfir Abdellah
}

\section{Resumen}

La cuestión amazigh se está actualmente erigiendo en el norte de África como problemática espinosa y altamente ideologizada vinculada a sensibles conflictos de identidad. Consecuentemente, en este trabajo planteamos un acercamiento histórico y científico integral que permita el reconocimiento cultural que la región merece.

Palabras claves: Amazigh, arabización, lenguas en extinción, transformación étnica, UNESCO.

\begin{abstract}
The question of the North African Amazighs is slowly emerging as a highly difficult and ideological issue because it is related to the sensitive problem of identity. All historical and scientific aspects need to be studied so that the region gains the recognition it deserves.
\end{abstract}

Keywords: Amazigh, Arabization, Algeria, languages in danger, ethnical alteration, UNESCO.

\section{INTRODUCTION}

Ancient Egyptian writings revealed the true history of the Amazighs, which dates back to about three thousand years BC. In ancient European languages, the Amazigh people were referred to with different names including the Moors (Mauri). The Greeks called them the Mazyes, while the Greek historian Herodotus used the Amazigh word Maxis. The ancient Egyptians called their Amazigh neighbours "the muddled". The Romans called them Numidians, or Libo. The Arabs often called them the Berbers. Berber in Arabic comes from the Graeco-Latin word Barbar, a Latin word used to describe all people who did not speak Latin or Greek believing Greek and Roman civilization superior to all others. The Berber or barbarian denomination was used by the Romans not only against the Amazighs but also against Germanic and English rebellious tribes. Some believe that the word is of Arab origin, on the basis that Berbers are of 
Arab descent. According to this theory, Berbers were Arabs who were deported from Yemen to North Africa by land and called Berber Arab land nomads. This theory has been refuted by researchers and scientists. DNA analysis performed on a large number of North Africans, ${ }^{1}$ showed that the E-M8I is I00\% of Amazigh origin. Genetic studies have shown that the percentage of Amazigh ancestry among Arabs is insufficient and that the Amazigh are local to North Africa.

The Amazighs have faced historical upheavals, conquests and invasions as well as attempts to obliterate their identity over thousands of years. These people live in a region representing a quarter of the African continent, from the Nile river to the Atlantic Ocean extending deep into the Niger and Mali deserts. Today, Arabic and not Amazigh is the region's official language and the language used in society. Nevertheless, the vast southern Sahara region, stretching from Senegal to Sudan's borders, as well as further communities, have maintained their Amazigh language.

\section{HOW DID ARABIZATION BEGIN IN NORTH AFRICA?}

First, it is necessary to distinguish between the spread of Islam and the imposition of Arabism. In fact, the former unfurled at a faster pace than the latter. Amazigh countries became Muslim over less than two centuries (during the $7^{\text {th }}$ and $8^{\text {th }}$ centuries), while their Arabization was never fully achieved to this day. The spread of Islam represented North Africa's first Arabization process, but the question remains as to why other people in different regions have not been Arabized; for example the Persians, Ottomans, and other areas of the Muslim world, such as Indonesia and others.

\section{MAJOR ARABIZATION EPISODES IN AMAZIGH HISTORY}

The ethnic transformation of the original Amazigh race to an Arab race can be explained by the Amazighs' initial religious wish to use the language of the Prophet, and the subsequent desire to adopt his Arab

1 «La découverte qui bouleverse l'histoire d' «Homo sapiens ». Article selected from the newspaper Le Monde (lemonde.fr, on 07/06/2017). See also: http://journals.plos.org/plosone/article/ figure?id=10.1371/journal.pone.0138453.g004. And also:

ـ تحليل الحمض النووي يثبت أنّ العرب ليسواعرباً، 15 يناير 2017 ( منذ عام واحد ) - الخبر أونلاين / و كالات 
affiliation. Thus, the idea that North Africa was formed by its inhabitants, indigenous Amazighs and migrant Arabs took root. Nonetheless, the whole population is actually formed by Amazighs, because Arabic speakers and inhabitants of Arab descent were all born to this North African Amazigh land, they were not migrants.

These Amazighs, who altered their etnicity to the Arab race, "played their part in Arabizing" the rest of the Amazighs, persuading them to "abandon their language and their ancestral customs" according to Mouliéras. ${ }^{2}$ Many Amazigh converts also adopted this attitude; they were ethnically transformed, they were proud of the fact and despised the non-converts and asserted that they were not Amazighs. The real Arabs in the Gulf countries respect the Amazighs, their language and their culture. This confirms that the Amazigh people are not real Arabs, but only ethnically motivated, which explains their hatred of their original race. Thus, every new ethnically Amazigh convert to the Arab race becomes a tool to convert more Amazighs from their Amazigh race to the Arab race.

In addition to this proliferation and continued Arabization -i.e. the conversion of the Amazigh race into the Arab race- everyone contributed to the destruction of Amazigh identity in North Africa, including the French. Amazigh people are today dispersed and under the sovereignty of various countries with different political systems. This explains the Amazigh movements within their borders as well as the policies of countries where Amazigh tensions exist. These political barriers hinder efforts to protect, promote and unify the Amazighs.

\section{THE ROLE OF FRANCE IN ARABIZATION}

I affirm that Arabism consisted in a process of controlling North Africa; in modern times, to Arabize the barbaric rebel regions against French colonialism as a reprisal policy. For me, Arabism is a modern French idea. Napoleon III spoke about an "Arab nation" in his ambition to create the so-called "Kingdom of the Arabs", ${ }^{3}$ extending from Morocco to the East in 1863. This idea, however, was rejected by the French Council.

2 Auguste Mouliéras, Le Maroc inconnu, Paris, J. André, 1895. p. 306.

3 Extracts from the letter of Emperor Napoleon III to the Duke of Malakoff, Governor General of Algeria, February 6, 1863. 
The colonial administration was the first to establish Arab offices in the provinces after the suppression of the Mokrani revolution in I87I. Subsequently, the names of many villages and cities in Amazigh areas were Arabized, and people were given Arab names in those same areas in I89I, the battle against the Amazigh.

They wanted everything to be according to the Arab tradition, Arabizing names, geographical regions and persons. To name a few, for instance Tariq ibn Ziyad was an "Arab leader" of twelve thousand North-African fighters that occupied al-Andalus. As for animals, what we hear today is the Arab horse, the Arab chicken, the Arab egg...

\section{AFTER INDEPENDENCE}

The regime pursued its targeting policy within its national Arab project, which contributed to the growing rejection of the Tamazight language by Kabylia people. A number of intellectuals and researchers attempted to define Amazigh language and culture. They also launched an academy based in Paris to collect and disseminate Amazigh heritage. But the issue ceased to be an elitist one and took on a public dimension when the researcher Mouloud Mammeri was forbidden from teaching courses at the university. Students were encouraged to take to the streets on ro March i980 to express their rejection of the exclusion policy adopted by the regime, concerning everything, which was related to the Tamazight. These student movements received significant response from residents in tribal areas: an unprecedented grand march was organised in Algeria, with demands that touched on Amazigh identity as well as democracy and human rights. Oppression followed, the requests were not addressed, leading to a range of subsequent conflicts.

After the Amazigh spring events, the struggle began to take on new dimensions, such as the democratic opening experienced in Algeria in the early i99os. It was followed by the establishment of the Amazigh Council by order of the president. The state's official media began to take Amazigh culture into account and broadcast in several Amazigh dialects.

Before 1996, Amazigh was recognized in the Constitution as a component of national identity alongside Arabism and Islam. In 1995, the 
Amazigh language was introduced into the curriculum in some parts of the country where Amazigh was the mother tongue.

In 2002, the state recognized Amazigh as a second official national language. The Amazighs celebrate Amazigh New Year's Day on I2 January, which has become a national holiday in Algeria. How is the Amazigh calendar followed in Algeria? - The Amazigh calendar is based on the solar system, and the agricultural New Year is the Amazigh New Year. The Amazigh calendar is not linked to any religious event, but rather to the history of the Amazigh defeat of the ancient Egyptians and the ascension of King Shoshenq I to the Pharaonic throne during the Ramesses in period. According to legend, this battle took place in Tlemcen, the Algerian city.

In 2009, a state television channel was launched to broadcast programs in Amazigh on all its channels. Worthy of note, there are several Amazigh dialects in Algeria, including the Kabylia, the Shawi and the Muzabi. Amazhig is an official language in Morocco alongside Arabic since 20II, and became an official language in Algeria in 2016.

\section{CULTURE AND EDUCATION}

Amazighs embrace Islam, most follow the Maliki doctrine, and others the Ibadi doctrine. In 1996, the Amazigh World Congress adopted an international cultural banner symbolizing Amazigh identity and cultural specificity across the world. This flag consists of blue, green and yellow colours, illustrating the Amazigh's natural environment. Blue symbolizes the colour of the sky and sea; green is the colour of the mountains and forests, while yellow represents the desert. In the middle, the Amazigh " $Z$ " is written in red, as this letter is part both of the word Amazigh and Izuran, which means roots.

Education programs are very influential in spreading the concept of Arabism and the idea of belonging to the Middle East. There is a clear tendency to marginalize North Africa's history in general and Algeria's in particular, and to adhere to a historical perspective centred on the East (an Arab-Islamic trend and focus on the Middle East). An example is that of a textbook: while a famous statue of the Emir Abdelkader may be on the cover of the book, the content of the book is unrelated to the Emir; 
forty illustrations of historical figures are linked to Egypt and Syria, while only four concern the Maghreb (Omar Mokhtar, Mohammed v, and of course Ibn Badis and Al-Bashir Ibrahimi). This must be understood as self-contempt and preference for all that is foreign.

More than $80 \%$ of textbook contents on this segment of Algerian history are dedicated to the Middle East. A generation has been created that knows everything about the Middle East and nothing about its homeland Algeria. Most books prefer to teach Middle Eastern literature and poets (Naguib Mahfouz, Abu Madi, Mutanabbi, etc.) rather than great local writers and poets. History books, especially those written in the 8o's, hardly refer at all to the history of Algeria or North Africa. Most of the teaching was limited to the modern Algerian state. References to the Amazigh civilization in history books were still linked to the Byzantine and Roman civilization in Algeria.

New Year's Day is the Amazigh's first and main celebration in Algeria and the entire Maghreb region. The Amazigh festival is celebrated every year on I2 or I3 January at the beginning of the Amazigh year - currently 2968 - and in the Amazigh language, January is pronounced Yennayer.

According to historical accounts, the celebration was the occasion of the victory of the Amazigh king Shashnaq over the Pharaohs in 950 BC, who ruled Egypt. For the Amazigh, this is a day of sacrifice, struggle and defence of the land. Other works interpret its meaning as the beginning of the agricultural year, the Vistbzron season of many yields; to celebrate, dishes based on wheat and vegetables produced by the land are prepared. It is an occasion to speak Amazigh Thimchrat, and that of social solidarity, caring for the poor and needy.

Almost all Amazigh regions in Algeria celebrate major religious events such as the month of Ramadan, Ashura and the Prophet's birth, as well as the Amazigh New Year. Villagers collect money, supervise operations, buy cows, slaughter and distribute their meat to poor families depending on the number of members. Celebrations relating to spring and the beginning of the harvest spread to the regions of Bordj Bou Arreridj and east of Algiers.

On March 2I each year, families take their young children out to enjoy nature. The day lasts until the evening, when they eat traditional dishes 
prepared with vegetables, as well as homemade bread based on wheat, barley, olive oil, oil or margarine and date dough.

\section{ENDANGERED LANGUAGES IN ALGERIA}

According to unEsco's Atlas report, which regularly lists endangered languages in the world, eleven languages are on the decline in Algeria. Degrees of vulnerability are differentiated by region. ${ }^{4}$

1- The Tamazight of Arzew (Arzew): Critically endangered according to UNESCO, barely 2000 people continue to speak the local variant of Berber in the Arzew region. If nothing is done, the language will inevitably become extinct.

2- Tayurayt (Cherchell): The Tayurayt language is one of the most vulnerable, spoken by 15,000 people in the Gouraya region and surrounding area.

3- Tasnucit (Tlemcen): The Berber language of Beni Snous is severely endangered, according to unEsco's classification. In this region of Tlemcen, considered a Berber island in western Algeria, local speech is sometimes related to the Rifain, and more particularly to Beni Iznassen. Today, only elderly people still speak Tasnucit. According to UnEsco estimates, there are around tooo speakers left.

4- Zenatiya (Tissemsilt): In the Ouarsenis and Tissemsilt regions, around 50,000 people still speak Zenatya, one of the variants of Zénète.

5- Tamzabit (Ghardaï): Vulnerable language, according to unesco's classification. It is spoken by 150,00o people, mainly in Ghardaï, in the Mzab Valley, El Ateuf and Berriane and Guerrara. The Mozabite language, however, seems to be well "spoken from birth to death", though restricted to family environments.

6- Taznatit (Timimoun): Zénète, or Taznant, is spoken by almost 80,000 inhabitants in the region of Touat out of a population of nearly 400,000 inhabitants. The Gourari, a local Arabic vernacular, has gradually overtaken the ancestral language.

7- Tidikelt (In Salah): Spoken in Ain Salah and in some surrounding

4 Publications of the United Nations Educational, Scientific and Cultural Organization (UNEsco) A detailed report on Amazigh languages and dialects that are subject to extinction. (UNEsco Atlas of the World's Languages in Danger): <http://www.unesco.org/languages-atlas/> 
oases, the Tidikelt language, with some 30,000 speakers, is declining according to UNESCO.

8- Tamacheq (Tamanrasset): It is vulnerable according to UnEsco experts. Around $\mathrm{I} 2 \mathrm{O}, 000$ people still speak this language, mainly in Tamanrasset (Kel Ahaggar) and Djanet (Kel Ajjer). Nevertheless, the Tuareg variants are the only Berber variants to have preserved the written form of the Libyan-Berber alphabet, called Tifinagh (or rather "Neo-Tifinagh" to be more precise), adopted by Algeria and Morocco in their attempt to make Tamazight official, thus removing the threat of total disappearance. The desert bluesmen may perhaps have to be relied upon to save the language.

9- Touggourt (Touggourt): The Touggout language from which the region took its name is spoken by a little over 8,000 people, according to UNESCO.

10- Taggergrent (Ouargla): This language dates back to more than 6,00o years and is concentrated in the age-old Ksar region after which it is named.

11-Tachenouit (Tipasa): Classified as vulnerable by unesco, the name "Tachenwit" comes from Mount Chenoua, which sits on the Mitidja. The Chenouis distinguish themselves by a number of original features, particularly language and traditions.

\section{CONCLUSION}

Current scientific research is interested in the Amazigh ethnicity. This nation is struggling to preserve its cherished culture and survive, refusing to be swallowed by other dominant cultures. The Amazigh do not, however, reject national taxations, nor scientific progress and logic. We must not forget that migrants formed the majority of the local population and that identity is given by the land, not by migrants: we are all Amazighs for territorial reasons, just as Mexicans speak Spanish but do not consider themselves Spaniards despite their Euro-Spanish heritage. 